ENSAYO

\title{
UNA ODA NERUDIANA DEL CANTO GENERAL
}

\section{Jaime Concha}

Análisis y comentario del poema de Neruda "Oda de Invierno al Río Mapocho”, perteneciente a su Canto General (1950). La “Oda” —advierte Jaime Concha — fue escrita en 1938 en un clima político y social muy diverso del actual y guarda relaciones estrechas tanto con la sección en que se publica (la sección VII, Canto General de Chile) y con la red de motivos fluviales que discurre por el conjunto de la obra. En este artículo se estudian los aspectos métricos, semánticos y formales del poema, en especial la estructura poética en sus imágenes y símbolos principales. Se concluye con algunas observaciones sobre el comentario como experiencia docente y las dificultades de su trasmisión por escrito.

Jaime Concha. Crítico literario chileno. Profesor de literatura hispanoamericana en la Universidad de California, San Diego, La Jolla. Autor de Neruda: 1904-1936 (Santiago: Editorial Universitaria, 1972) y Tres Ensayos sobre Pablo Neruda ([1972] University of South Carolina, 1974). Ha enseñado en Chile, Ecuador, Francia y los Estados Unidos, y publicado estudios monográficos sobre poetas latinoamericanos del siglo XX (Darío, Neruda, Mistral y Huidobro).

Estudios Públicos, 101 (verano 2006). 
Oda de InVIERno AL Río Mapocho*

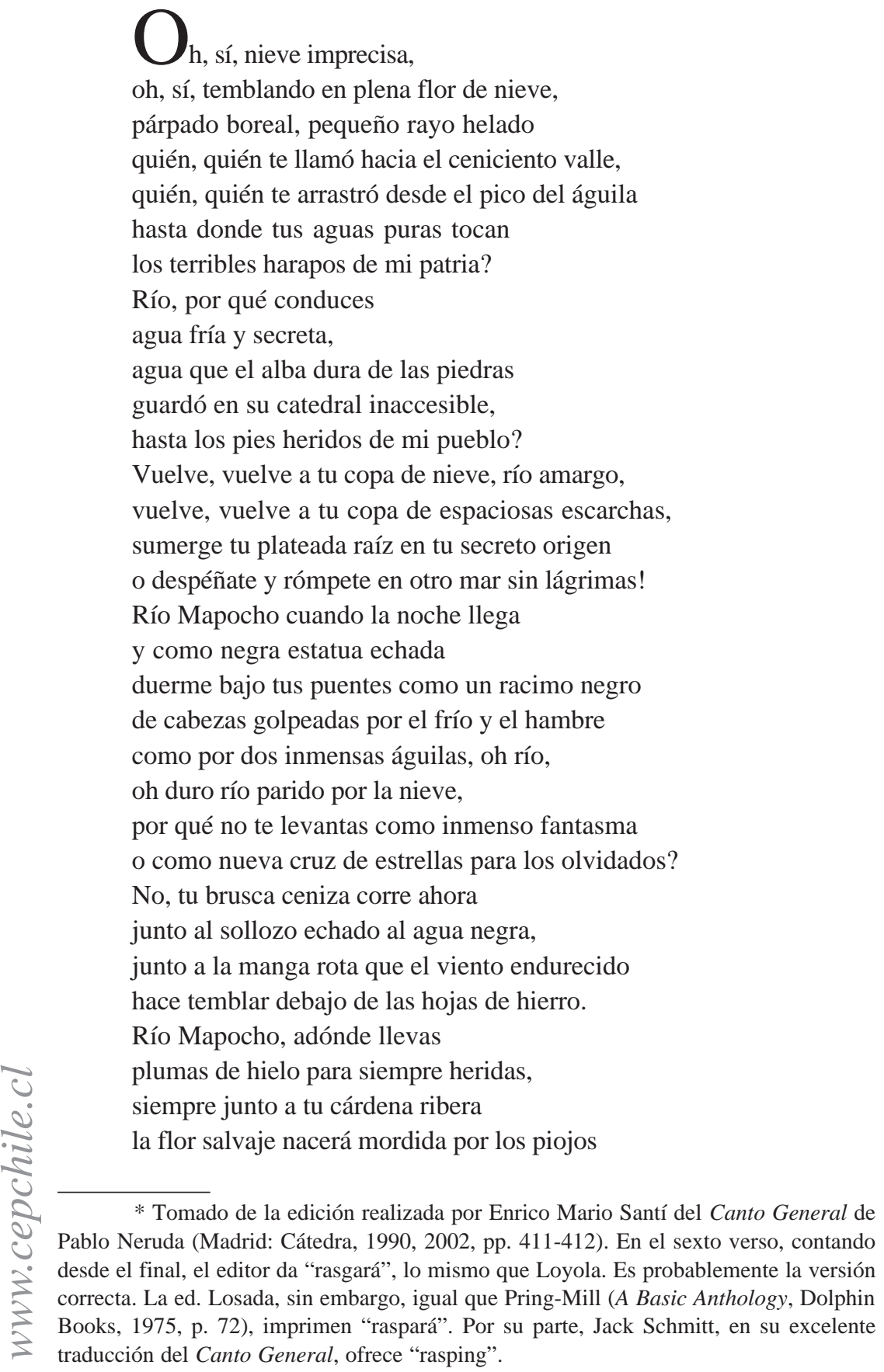


y tu lengua de frío rasgará las mejillas

de mi patria desnuda?

Oh, que no sea,

oh, que no sea, y que una gota de tu espuma negra

salte del légamo a la flor del fuego

y precipite la semilla del hombre!

\section{Preliminar}

Leer un poema es impregnarse de su fuerza emocional, que nos puede conmover hondamente, comunicándonos destellos de conocimiento, a veces de iluminación. En la impresión inmediata y global que recibimos, vemos un conjunto de palabras entrelazadas, que se combinan e irradian con química singular; las estrofas existen como "islas encantadas" (Ortega) o flotan unidas en la corriente viva del poema; un tono, múltiples tonos, vibran con tristeza, congoja y desconsolación, o con gracia o con cólera, según sea el ánimo que preside el poema, el ritmo que lo configura. "Clara y oscura” es la poesía, la caracterizó hace ya tiempo Aristóteles en un pasaje olvidado de su Retórica. Diáfana y misteriosa, diríamos hoy.

Comentar un poema es leerlo, releerlo, estudiarlo para tratar de comprender su sentido, describiendo las relaciones internas que lo constituyen y estableciendo los nexos conceptuales que sean pertinentes (o relevantes). Este conjunto de operaciones es lo que quizás podría designarse como interpretación de un texto. Esta vieja práctica que, como todo lo importante en las letras divinas y humanas (teología, humanidades) proviene de una doble fuente, la antigua y la judío-cristiana, nace ligada a los grandes sistemas de la filosofía griega y tiene sus momentos más destacados en la época alejandrina, en el mundo medieval (teoría de la exégesis y doctrina de los cuatro sentidos), durante el Renacimiento (Valla y Erasmo son entonces los maestros indiscutidos en la filología y crítica del Nuevo Testamento) y entra en los tiempos modernos bajo la doble égida de Schleiermacher y Dilthey - conexión cuyo aporte será capital para el ingreso del método hermenéutico en la esfera de lo estético, de las ciencias históricas y de las manifestaciones literarias. Este último pensador, a través de nociones como individualidad, vida y vivencia (Leben, Erlebnis), expresión y, sobre todo, de la categoría de "comprensión” (Verstehen) — expuesta principalmente en su Introducción a las Ciencias del Espíritu (1883), pero ya esbozada en sus cartas y diarios poco después de 1850—, echará las bases para la posterior universalización de la interpretación como estructura fundamental del 
existente humano (Heidegger, Ser y Tiempo, 1927, prfs. 26 y 27). La interpretación, que comienza siendo amena conversación sobre versos de Homero en uno de los primeros diálogos de Platón, el levísimo Hipias Menor, y que en Aristóteles será anatomía de la tragedia (Poética) y descripción y análisis de la estructura del juicio declarativo en su Organon (Peri Hermeneías o De Interpretatione), deja de ser técnica textual de documentos religiosos, legales o poéticos y se convierte esencialmente en una noción filosófica decisiva en cuanto estructura básica del Dasein ("existenciario" en la traducción de Gaos). En el caso particular de Dilthey, al concebir la comprensión como experiencia de vida compartida, se formula la ecuación expresión = comprensión, que dará una orientación claramente espiritualista (y psicológica, en el sentido de su psicología descriptiva) a la investigación de los fenómenos de creación en las ciencias humanas. Creatividad, intuición, fantasía, esquemas, etc., serán parte del vocabulario más frecuente en el vasto corpus diltheyano, que hemos podido conocer en el dominio hispánico gracias al valioso esfuerzo de traducción y de exposición de Eugenio Imaz. Entre la "comprensión” diltheyana y el Verstehen heideggeriano se va a plasmar un capítulo clave en el desarrollo filosófico contemporáneo ${ }^{1}$.

En nuestro modesto panorama chileno, estas cuestiones entran en la Universidad en la forma de los estudios estilísticos, no siempre bien diferenciados de las corrientes de análisis de orientación fenomenológica (Martínez Bonati será el primero en partir las aguas y diferenciar netamente ambas tendencias). Ya hacia 1950, o en su alrededor, la estilística de procedencia alemana y española (Spitzer, los Alonsos) empieza a ser materia de reflexión y de práctica, creando las bases para un nuevo acercamiento, más técnico y elaborado, al texto literario. “A los textos mismos” parecía ser entonces la consigna metodológica del momento. Nada de biografía ni de historia, por lo tanto. Un instrumento valioso en esta situación fue el libro de Leo Spitzer, Lingüística e Historia Literaria (1948), traducido convenientemente en Gredos (el sancta sanctorum editorial de la época, en el que Agustín Cueva, con cierta exageración, solía ver un alcázar académico franquista); en él, de un modo didáctico, el profesor austríaco trasladado a los Estados Unidos (Johns Hopkins, Harvard) exponía autobiográficamente su formación y desarrollo como lingüista e historiador literario, en el marco de la romanística europea y de los estudios medievales especialmente franceses (fue discípulo de F. A. Becker, lo cual lo vinculaba indirectamente con Friedrich Diez, el

${ }^{1}$ Bréal dedica un par de páginas notables de su Essai de Sémantique (1897) a la raíz "sta" de episteme, Verstehen y understanding, y la ve ligada a destrezas y juegos competitivos como lanzar la jabalina, etc. (cf. Essai de Sémantique, 1924, pp. 198200). 
fundador de la lingüística romance y, ya más cerca, con los estudios de épica francesa iniciados por Gaston Paris y su revista Romania). La Estilística, entonces, tal como fue conocida por nosotros a mediados del siglo XX, tenía coloración romanista, una matriz romántica y una metodología marcadamente espiritualista.

La idea central del libro de Spitzer, expuesta en su ensayo inicial, es un intento de aplicación del círculo hermenéutico, mediante el cual la comprensión intuitiva del detalle significativo permite el acceso a la captación del todo - el "centro vital interno", como lo designa el autor con su pizca de tropicalismo vienés. El detalle o los detalles — los étimos espirituales en la terminología de Spitzer - son las expresiones anormales, que llaman la atención una vez que se supera la lectura lisa, en superficie, del texto. Observando ahí mismo la singularidad de los nexos causales en Charles-Louis Philippe (un narrador muy difundido a comienzos de siglo, hoy totalmente olvidado) y estudiando en los ensayos siguientes "El Perspectivismo Lingüístico en el Quijote” o "La Enumeración Caótica en la Poesía Contemporánea”, proyecta en distintos dominios lo expuesto y propuesto en su decisivo artículo inicial ${ }^{2}$.

En los años sesenta otro tipo de intereses y preocupaciones tiende a dominar en el país y halla su cauce en el interior de las universidades. Se vio, así, en la estilística y en su armazón teórica un método de carácter idealista por la base intuitiva de su epistemología. La historia, las ideologías, la crítica social —inquietudes intelectuales del momento— no parecían encontrar cabida dentro de las posibilidades que ofrecía la nueva disciplina. Lukács sancionaba todo esto con un tajante rechazo de ella como saber incapaz de ir más allá de sus bases subjetivas ${ }^{3}$. Curiosamente, éste era el mismo Lukács que en uno de sus grandes escritos inaugurales, la Teoría de la Novela (1914-1920), postulaba una clasificación de las especies narrativas bastante afín a la tipología de las concepciones del mundo ideada por Dilthey en sus últimos años de producción intelectual.

Lo característico de ese tiempo, por lo menos para quienes nos interesábamos en el análisis literario y en el comentario de textos, fue combinar (¿conciliar?) la comprensión textual del poema o de una obra literaria con la investigación empírica de sus orígenes histórico-sociales y de su contexto

\footnotetext{
${ }^{2}$ El ensayo de Spitzer sobre "La Enumeración Caótica en la Poesía Contemporánea” no aparece en la edición norteamericana de Princeton y había sido ya traducido y publicado por Raimundo Lida (Buenos Aires: Colección de Estudios Estilísticos, 1945). No hay que olvidar que Lida es también uno de los primeros traductores de Heidegger al castellano (“¿Qué es la Metafísica?”), en uno de los primeros números de la revista Sur.

${ }^{3}$ Lukács, Gyorgy: Estética, III, p. 177 passim, 1967.
} 
ideológico. Probablemente una tarea imposible, cuando no francamente contradictoria. El 11 de septiembre de 1973 resolvió nuestras dudas y aporías manu militari. La Junta tenía la indudable ventaja de desconocer olímpicamente las especulaciones de un Spitzer o de un Lukács y toda la parafernalia de nuestros estudios humanísticos. Con tino y savoir faire, optó por el estructuralismo. Se pudo, entonces, lacanizar a rienda suelta, semiotizar a troche y moche.

\section{Lugar del poema}

El poema que se llama “Oda de Invierno al Río Mapocho” ocupa un lugar bien definido en el Canto General. Desde un punto de vista cronológico, es uno de los primeros, si no el primero en sentido absoluto, con que Neruda da comienzo a la redacción de su gran poema; desde el punto de vista sincrónico, se halla situado al fin del Canto General de Chile, en una de las secciones centrales en la disposición del libro.

Genética y diacrónicamente su puesto es significativo. Neruda ha vuelto recientemente a Chile para establecerse definitivamente en el país; el poema es hasta cierto punto un reencuentro con su tierra, con su "patria" y su "pueblo", como dirá ahí mismo. En tal sentido hace par y pareja con "Himno y Regreso", su coetáneo, pieza que abre de hecho el Canto General de Chile (el fragmento "Eternidad" pertenece al tipo de introducciones que se escriben casi siempre a posteriori). "Himno y Regreso" lleva fecha de 1939 y se publica al año siguiente; la "Oda” es de 1938. Entre ese himno y esta oda se articula toda la sección VII del Canto General.

Otro texto que disputa a la presente oda su condición de célula original de la epopeya nerudiana es el relativo a Almagro, que halló después su sitio en Los Conquistadores, pieza número xviii, bajo el título de "Descubridores de Chile”. La tensión geográfica es aquí importante. Si el de Almagro es el poema del norte y de la invasión nortina, la "Oda”, como el título mismo lo indica, se sitúa en el plexo central del país: en su capital y en el río que la atraviesa. Norte y centro son, así, los puntos cardinales en un mapa territorial en que se enfrentan y complementan una historia en profundidad, la de la conquista, y una triste actualidad como condición del país, tal como Neruda la percibe en 1938 al comenzar su Canto General. Vale la pena fijar aquí datos, fechas y otras circunstancias.

Tanto Loyola como Santí, autoridades en la materia, coinciden en ver los dos poemas como las piezas más tempranas en la génesis del Canto General. En su bibliografía, indispensable para todo estudioso de Neruda, el crítico chileno encabeza con la "Oda” la lista de piezas sueltas que prece- 
den la publicación del libro; en sendas anotaciones el crítico cubano, editor del Canto General (CG), describe acertadamente el complicado intríngulis de fechas, prioridades y la opinión de algunos especialistas:

Descubridores de Chile. Primera publicación. Con el título de “Almagro", en La Hora (Santiago de Chile) 21 de julio de 1940; también incluido en el Canto General de Chile. Fragmentos (México, 1943) e Himno y Regreso, vol. 10 de Obra Poética de Pablo Neruda (Santiago: Cruz del Sur, 1948). Es el poema más antiguo que Neruda incluyó en el CG. Según Margarita Aguirre (Genio y Figura de Pablo Neruda), el poeta lo escribe el 7 de mayo de 1938, día en que murió el padre de Pablo Neruda. Este dato ha hecho que críticos como Rodríguez Monegal y Felstiner lo vean como el origen (la "oscura raíz”, en célebre frase de aquél) de CG.

“Oda de Invierno al Río Mapocho”: Uno de los primeros poemas publicados del CG: Revista de las Españas (Barcelona) 103-104 (julio-agosto de 1938) y, simultáneamente, Aurora de Chile (Santiago) 1 (agosto de 1938) y Ruta (México) 5 (agosto de 1938). Según De Costa, el poema es el verdadero origen del $C G^{4}$.

De estas constataciones es posible desprender un par de cosas. En primer lugar, la cercanía extrema de los poemas. En efecto, entre comienzos de mayo, en que se supone que Neruda habría escrito su “Almagro”, y la aparición a mediados del mismo año del otro poema en España, México y Chile transcurren menos de dos meses, tiempo brevísimo si se imaginan la concepción, redacción, envío e impresión del texto. Ambos poemas resultan, por lo tanto, prácticamente simultáneos. En segundo término - y esto es muy sugerente- el radio de las publicaciones coincide con las primeras zonas históricas y geográficas del Canto General. España, México y Chile: triple amor nerudiano que está en la base del Canto General. México y Chile son obvios, y no llaman la atención de ningún lector que recorra sus 15 cantos. La función de España es menos clara; pero, como traté de exponer en otra ocasión, el Canto General es, a su modo, una América en el corazón, en plena continuidad con su libro sobre la Guerra Civil ${ }^{5}$. Las raíces editoriales del libro brotan entonces en el mismo terreno de su simpatía por tres pueblos a uno y otro lado del Atlántico, configurando así un hispanismo de dimensión hispanoamericana, volcado no hacia una tradición pasatis-

${ }^{4}$ Pablo Neruda: Canto General, ed. Enrico M. Santí, 1990, 2002, pp. 169 y 411.

${ }^{5}$ Concha, Jaime: “A Orillas del Canto General”, ponencia de 1993, inédita, por aparecer en la Revista Iberoamericana y en las Actas del congreso nerudiano de Santiago organizado por Manuel Jofré. 
ta, sino hacia las luchas del presente y del futuro inmediato —una España derrotada, pero aun combatiente; naciones encadenadas a la propiedad oligárquica de la tierra, que entrarán muy pronto en el vórtice de la Guerra Fría, etc.

La vecindad temporal de los poemas halla también confirmación en la convergencia de imágenes y símbolos principales. La presencia de la nieve es natural, desde luego, en cuanto paisaje del descubrimiento de Almagro y fuente andina del Mapocho; pero la imagen del "águila marina”, al fin del primer poema, se dobla en un fuerte símbolo (con cambio de hábitat) que va a ser central en la concepción ideológica de la "Oda”. De este modo, si se considera a grandes líneas el desarrollo nerudiano y si se ve in conspectu su poesía previa a 1938, estos poemas destacan por su indudable novedad. Una afirmación de la historia ha emergido, se impone la presión del referente colectivo, todo lo cual no hubiera sido posible sin la experiencia de Neruda en la Península. España le ha enseñado a ver la historia y a mirar con nuevos ojos, por primera vez, su propia patria. La bivalencia, que será característica en su valoración de la herencia española, deriva justamente de eso, de ver que los países no son nunca una unidad efectiva y que pueden entrar en colisión, a veces mortal y fratricida.

\section{La sección VII}

En el plano de la composición, es decir, según el orden en que se lo dispone para la experiencia de lectura, el poema interactúa en un doble haz de conexiones. Conexiones con la sección, con el Canto General de Chile que la "Oda” cierra y corona; conexiones más amplias, innumerables a decir verdad, con la arquitectura de la epopeya en su conjunto. En este segundo caso, es necesario someter el análisis a una drástica restricción, considerando solamente la red de motivos fluviales de que el poema participa. Como en seguida comprobaremos, el Mapocho es sólo uno, uno de tantos elementos, en el gran mapa de ríos que irriga el Canto General (véase infra, apartado "Un arte de ríos").

Como decíamos un poco más arriba, la sección VII se inicia con el fragmento "Eternidad", continúa con "Himno y Regreso" (1939) y finaliza con la "Oda de Invierno al Río Mapocho". Entre esos extremos se halla una serie de poemas, 17 en total, que despliegan la típica vena enciclopédica del libro (enciclopedia poética), revelándonos el país en su aspecto geográfico y geológico, en sus seres animales y vegetales, en la dimensión humana que al poeta le es más cara, la de su grupo de amigos. Las catástrofes son también tema de esta poesía. En otros poemas, más autobiográficos sin 
duda, el poeta nos habla de su lejanía de Chile y del sentimiento que lo invade en esas circunstancias. La tónica general es de poemas de alta calidad, casi siempre densos y complejos, en que figuran especímenes notables de su largo y ancho cántico. Catarata de poesía que se ve coronada por la “Oda al Mapocho”, cúpula en gran medida levantada por todo el despliegue anterior.

Ya "Eternidad", sostenida por el ánimo aún residenciario de exploración geológica, pone el acento en el orden cósmico originario, en la riqueza de los estratos subterráneos y en la floración acuática que es una de sus manifestaciones: "De dónde vengo sino de estas primerizas, azules / materias...”, con lo que se asigna a la raíz cosmogónica el mismo color con que fuera descrito el fondo creador en Residencia en la Tierra. Allí mismo "primerizas" tiene casi un matiz verbal, como si lo primero y lo primordial gestara el impulso genésico que da a luz la variedad del mundo.

Esta zona de la realidad material se privilegia a continuación produciendo la máxima ecuación constitutiva del Canto General, equivalencia whitmaniana habría que llamarla, en la medida en que es una clave de bóveda de Leaves of Grass - entre el macrocosmos y el sujeto, entre el continente y el cuerpo individual, entre el agua y la tierra por un lado y la sangre por otro: "en la noche duermo como los ríos (...) y toco / en un camino de ríos lo que no distribuye / sino la rosa nunca nacida...”.

Los próximos poemas, a la vez que refuerzan la visión constante e intermitente del río (el río Toltén en "Quiero Volver al Sur" (1941); y en "Melancolía cerca de Orizaba” (1942) se marca con claridad la preferencia nerudiana en el mismo inicio: "Qué hay para ti en el Sur sino un río...”), van a pronunciar con fuerza y con relieve palabras como "patria” y "pueblo", que llegarán a ser esenciales en la construcción poética y conceptual de la "Oda”. La patria, que se nombra y abraza con honda emoción, es algo todavía balbuceante. Neruda empieza a descubrirla gracias a su experiencia internacional. Y es algo sobre todo problemático, porque por doquiera dominan fuerzas que la niegan y mutilan. No es algo dado ni nada preexistente, sino un espacio que está por crear y que debe ser creado. Patria hija, en consecuencia, para la cual hay que asegurar una voluntad decidida, tensa y afirmativa. "Sea yo" proclama por dos veces en el poema iii, con fórmula que veremos retomada y transformada en la "Oda”. El pueblo, por su parte, es visto desde un ángulo doble, activo y pasivo al mismo tiempo. Es agente colectivo de un trabajo creador en las humildes artesanías populares; es víctima permanente en las tragedias de la naturaleza que afectan regularmente al país. Sobre esta repartición de los males que Neruda ya comienza a verificar, escribe uno de los pocos pasajes en que su nuevo credo político 
se hace explícito (probablemente el terremoto de 1939 está presente, y las inundaciones de esos años): "El agua no sube hasta la casa de los caballeros / cuyos nevados cuellos vuelan desde las lavanderías / como este fango arrollador y estas ruinas que nadan / con sus muertos..." (en "Inundaciones").

En suma, la sección VII aporta materiales poéticos de diversa índole a la "Oda", que culminan y hasta cierto punto son resumidos y sintetizados en ella. Un tembloroso sentimiento de la patria y del pueblo ha surgido, que empieza a ver con cólera creciente la distribución social de los males —revelación en negativo de la también injusta repartición de los bienes. A medida que nos acercamos al fin de la sección el paisaje acuático pasa a dominar. "Jinete en la Lluvia” y "Mares de Chile” anteceden inmediatamente al poema que ahora pasamos a comentar.

\section{Título}

El título mismo de la “Oda de Invierno al Río Mapocho” expresa un contenido triple, indicando el género o subgénero al que el poema pertenece, la circunstancia temporal que lo envuelve y el destinatario elegido e imaginado por Neruda.

En su clasificación de las especies líricas, Hegel parte distinguiendo los himnos de las odas. Los distingue cuidadosamente y dedica esfuerzo a precisar su pensamiento. Pone juntos y menciona en serie homogénea "himnos, ditirambos, peanes, salmos”, subrayando claramente su origen religioso, aunque observa que tal tipo de poemas no debe estar destinado solamente a la "edificación religiosa", litúrgica o cultual". Es claro que en Hegel está implícita la doble fuente del himno como género poético, la bíblica de los Salmos y la griega de los Himnos homéricos. La relación del poeta con su destinatario divino o divinizado es vertical; el poeta clama a él o lo ensalza en una actitud de reverencia que muchas veces tiende a negar su subjetividad.

En lo que respecta a las odas, Hegel insiste en la independencia del poeta, en la plena asunción de su subjetividad, y ejemplifica con interesantes anécdotas tomadas de Horacio. El fervor religioso que aún es posible ver en los epinicios de Píndaro — poeta del que Voltaire solía decir que todos lo alababan, pero que nadie lo había entendido en realidad—, dedicados a dioses, héroes y agonistas, es más bien el fervor por la comunidad victoriosa en la que el poeta participa. En Horacio el proceso de interioriza-

${ }^{6}$ Hegel: Vorlesungen uber die Aesthetik, 1970, B. III, pp. 415 ss. 
ción, en el que Hegel pone el acento, siempre preocupado por su bendita triplicidad, ya se da de un modo completo, según el autor de las Lecciones sobre Estética. En la oda, por lo tanto, el poeta y su objeto entran en una relación de inmanencia consumada: es a un "tú" al que ahora se dirige.

El destinatario de las odas es casi siempre un sujeto humano - personalidad destacada, héroe de la comunidad, o victorias y sucesos en que el talento y el genio del hombre han resultado triunfantes. Piénsese, por ejemplo, en la famosa oda a la vacuna de Quintana y su traducción por el joven Engels. Esto es parte del gran desarrollo que la oda cívica adquiere en los siglos XVIII y XIX. Menos habituales son las odas dedicadas a elementos de la naturaleza, que irrumpen con el romanticismo y se hacen más frecuentes en el mundo de habla inglesa (Keats, Shelley, pero también Hugo). Tal vez Neruda pudo hallar un antecedente egregio en el Siglo de Oro español, en la gran oda de Fray Luis al río Tajo, llena de resonancias históricas igualmente catastróficas. Si no la conoció en la Península pudo conocerla antes, incluso en Chile, pues era común en los manuales de literatura, gracias al ojo antolójico (sic) del benemérito don Marcelino. En ese poema, el Tajo que profetiza al rey don Rodrigo los males que su conducta acarreará a España, interpela a otro río, el Betis, vaticinando a la patria goda que todo ello "iay!, te condena / ¡oh, cara patria!, a bárbara cadena”.

La determinación temporal "de invierno" es también interesante. Se trata de un modificativo adverbial que a veces usa Neruda en títulos equívocos. La oda no es parte ni pertenece al invierno, está hecha durante el invierno. "Maestranzas de Noche" fue bien vertida al francés como "Les Ateliers la Nuit", y no "de la Nuit".

Ahora bien, no puede haber contraste más grande entre esta oda invernal de Neruda y las preciosas "invernales" a que nos tuvo acostumbrados Darío. La "invernal” modernista es poesía de interior, intimista, de una intimidad casi siempre suntuaria. Recuérdense el maravilloso "Invernal" de El Año Lírico de Azul, y "De Invierno”, soneto añadido en la segunda edición del mismo libro. Intimismo cálido y recoleto en el interior de una pieza, ambiente sensual de garçonnière parisina. En el extremo opuesto de ello, palpamos en la "Oda" la intemperie en plenitud, un poema de invierno en que el frío, la miseria y la suciedad estallan con fuerza avasallante. La mejor poesía hispanoamericana describe visiblemente un arco imperioso, cruza a grandes trancos leguas de conciencia social y de compromiso histórico. El poema nerudiano representa, por lo tanto, un lazo a lo mejor asumido con un espécimen del Siglo de Oro y un distanciamiento de época con la tradición modernista (lo cual nunca opacó la inalterable admiración de Neruda por la obra del nicaragüense). 


\section{Métrica}

Desde un punto de vista métrico, la "Oda" se inicia con dos versos muy frecuentes en la poesía del Siglo de Oro, el heptasílabo y el endecasílabo, que van a constituir la mayor parte en la construcción del poema: "Oh, sí, nieve imprecisa, / oh, sí, temblando en plena flor de nieve”. De un modo aproximado y tendencial, si se tiene en cuenta el lugar que este tipo de versos ocupa en el poema, éste toma un aire tradicional de silva, en forma de composición continua, sin divisiones estróficas de por medio. Sus goznes naturales y sus articulaciones lógico-rítmicas no quiebran la cascada ininterrumpida de versos, sin blancos ni espacios de separación internos. Así, el primer movimiento de la "Oda” termina en dos impecables endecasílabos (por su metro, ritmo acentual y tensión estructural): "hasta donde tus aguas puras tocan / los terribles harapos de mi patria?”.

Predominio relativo, entonces, del par de 7 y 11 sílabas, sobre todo porque envuelve el poema, surgiendo en sus momentos más destacados. De hecho, en los 12 primeros versos de la "Oda", casi un tercio del total, sólo dos escapan de este módulo. Es claro, con todo, que hay otros códigos coexistiendo y que con él se conjugan. Sutil y efectivamente, los versos se extienden a 12, 14 y 16 sílabas, con cierta preferencia por el alejandrino renovado de Darío. En el conjunto del poema hay, por lo menos, 8 magníficos alejandrinos, de cesura muy exacta, lo cual, es innecesario recalcarlo, suma su efecto a la presencia múltiple del heptasílabo. Ambos sistemas se imbrican, fecundándose mutuamente, pues el hemistiquio alejandrino funciona como una especie de kolon (por ejemplo, el verso "párpado boreal, pequeño rayo helado", que en la "Oda” se presenta en una sola línea, puede dividirse perfectamente en dos kola de 7). Y a este par hay que agregar las preferencias de un gran poeta que nunca fue un renovador y creador original en el dominio métrico y de la eufonía, cuyo verso, desde las Residencias en adelante, estará siempre caracterizado por una musicalidad sorda, hecha de intensidad y monotonías, musicalidad opaca, buscada deliberadamente por el poeta. En la esfera métrica es fácil apreciar cuán poco versolibrista fue Neruda y qué poco se apartó de las tendencias tradicionales del verso castellano. La anécdota según la cual Neruda atribuía a los chilenos el hablar en endecasílabos es una boutade de doble filo, que desenmascara lo unilateral de su oreja métrica. A la vez, gran parte de la fuerza de su poesía y su vasta proyección en la audiencia colectiva, se deben a que no rompe substancialmente con hábitos seculares del verso en la tradición castellana. 
Resumiendo: tres distintos sistemas métricos, tres distintas maneras de modular el verso coexisten y se yuxtaponen en la "Oda": el código del Siglo de Oro, con la silva de 7 y de 11; el repertorio modernista dariano, más sensiblemente simétrico (ya que no eufónico) en el juego de los alejandrinos; y las preferencias particulares del poeta, hecha de alargamientos, dilataciones... Los tres se suman para producir esa "vacilación entre el sonido y el sentido" en que consiste todo poema (Valéry).

\section{Aspectos formales}

El eje principal en que gira el poema es la relación tensa y sostenida entre sujeto y objeto, la voz y los tonos del poeta por un lado y la mención constante del río cuando se lo invoca y describe, por otro. Relación dialéctica, sin duda, de ida y vuelta, en que el sujeto crece y se alza, elevando su voz en lamento, imprecación, deprecación o cólera debido a los aspectos que el río va mostrando en su metamorfosis. Eje transversal, que se desplaza entre sus polos subjetivo y objetivo y que pone en marcha el mecanismo constitutivo del poema.

Este desplazamiento transversal hace pendant con otro eje progresivo, vectorial, que se manifiesta en sus coyunturas más tangibles mediante exclamaciones, interrogaciones, afirmaciones, negaciones y apóstrofes. Estos cambios de énfasis, que levantan la elocución más allá del plano declarativo normal, se dan en instantes precisos en el discurrir del poema.

Si las exclamaciones más destacadas se distribuyen en los extremos de la "Oda", las preguntas e interrogantes abundan más, cruzando todo el espectro intelectual del inquirir y de la causalidad: "quién, quién”, "por qué”, “adónde”. Preguntas por el agente del mal, por la causa y razón del mismo, etc. que hacen de esta actitud de búsqueda y conocimiento un componente esencial en la estructura ideológica del poema. El poeta busca saber, busca explicaciones para lo que tristemente comprueba.

Ahora bien, hay un punto nodal en el poema en que la formulación interrogativa del poema cambia de sentido; y esto es literal. En vez de preguntar y de insistir en el "por qué", se clama ahora: "por qué no te levantas...", con lo cual se pasa a otro plano de posibilidades humanas, ya no únicamente lógico-intelectual. Y el imperceptible "no" que aquí se intercala permite el vuelco, casi de inmediato, a una gran negación. "No" dice enérgicamente el poeta, preparando el magno rechazo, doblemente acuñado, en el desenlace de la "Oda”. Se lo ve: “Oh, sí”, “No”, “Que no sea” es el triple gozne y articulación del poema, en un tipo de organización que empezamos a vislumbrar como dialéctica. Por el momento, en el plano formal en que aún 
se mueve el comentario, basta reconocer en ella los mínimos y potentes eslabones que vertebran su arquitectura.

Junto a esto, es posible observar en el poema una serie de duplicaciones, en la forma de ecos o rebotes, a veces es disposición visiblemente paralelística. Son muchas, y muy evidentes. Y si se relee el poema con atención, se observará que prácticamente todo signo importante del poema vuelve a ser pronunciado, levemente transformado a veces: "flor de nieve, flor de fuego”, “pico de águila, inmensas águilas”, “aguas puras, agua negra”, etc. Y es claro que este signo del dos, esta marca dual que da impronta al poema, debe tener una justificación más amplia, que la explique y le confiera sentido.

En efecto, el lector del Canto General advierte fácilmente que la mayoría de los cánticos que lo componen se abren con ecos y repeticiones del mismo tipo de los descritos. En el inolvidable inicio de la epopeya, el segundo verso es éste: "fueron los ríos, ríos arteriales. "Del aire al aire...” es el comienzo famoso de Alturas de Macchu Picchu. El inicio de la sección Los Libertadores reza: “Aquí viene el árbol, el árbol / de la tormenta...”. “Tal vez... / tal vez, tal vez”, repiten los versos primero y cuarto de La Arena Traicionada. "Eternidad”, ya aludida más arriba, empieza: “Escribo para una tierra recién secada, recién / fresca de flores...”. Es claro que la geminación verificable en la “Oda” reproduce y encapsula lo que, en gran escala, se va a expandir a lo largo del Canto General. Es su cifra minúscula, su número áureo.

\section{Sentido inicial}

Título, métrica, ensambladura interna ponen el foco del poema en un elemento de la naturaleza, en un río que tiene una posición central en el país, por su nexo geográfico con la capital y, en lo histórico, por su relación con la conquista, con la fundación de Santiago y con la resistencia indígena - que comienza también, como nadie parece recordar, en un fausto y aguerrido 11 de septiembre.

Neruda no intenta en su poema un paisaje fluvial. Su oda no es descriptiva como muchas decimonónicas, románticas o neoclásicas (de Bello, por ejemplo). Recurre a momentos cruciales en el curso del río para hacer resaltar el perfil que le interesa: la cuna andina del río, su cauce hacia el Valle Central, la oleada de frío y de miseria que va sembrando en torno suyo, etc. En lo físico y espacial, un fuerte contraste se acusa entre las alturas de donde proviene y el valle al que adviene y se incorpora: "espaciosas escarchas", "valle ceniciento”. Con ello, Neruda hace sensibles dos 
aspectos relevantes en el cuerpo geográfico de Chile, que se cargan de valores y valoración históricos. Posiblemente es ésta la mutación decisiva que se da en el poema. El río se historiza, deja de ser materia y naturaleza y pasa a ser paisaje social, encarnación de injusticia, lacra antihumana que ulcera el país. En sus aguas sucias, especialmente durante el invierno, el río refleja diariamente esa contradicción. Lo que era utopía de pureza en las nieves cordilleranas (una de las dos utopías más activas en el Canto General; la otra es el maíz color de oro depositado sobre los techos del Norte Chico), da paso a la degradación, al valle de lágrimas de los débiles e indefensos. El mensaje social queda entonces grabado en el agua y en la tierra, en el viento y en la noche invernales, que soplan contra la carne inerme de los "olvidados" — notable hallazgo que Neruda emplea mucho antes del film de Buñuel y del poema que el mismo inspirara a Prévert.

Neruda fija entonces un sitio, un plexo desde donde habla y al que habla. Es su fuerte voluntad de radicación en el nuevo territorio descubierto —el corazón de Chile, su nueva y definitiva "residencia en la tierra”. Esto que allí ve todavía no es patria: es una suma de harapos y de piojos, restos de un pueblo maltratado y sistemáticamente despreciado. A medida que la "Oda" transcurre, adquiere una genuina grandeza, inconfundible autenticidad. A través de la radiografía severa de un río, se nos revela en consecuencia el fracaso histórico de la propia comunidad.

\section{Estructura poética}

Estos materiales dispersos (nieve, río, tierra, valle) cuajan definitivamente en lo que con mayor justeza puede designarse la estructura del poema, su estructura poética propiamente tal. Ella ha sido estudiada habitualmente (por caso, en la explicación de textos de tipo tradicional) recurriendo a categorías de la retórica clásica, las figuras de los siglos XVII y XVIII e incluso más cerca de nosotros. Indudablemente, el credo romántico y su influencia internacional contribuyeron en mucho a cambiar este panorama, el acentuar la individualidad del creador y el carácter original de su creación. Hasta cierto punto, el recurso a la retórica tenía bastante justificación histórica, en la medida en que, como su nombre lo indica, ella nació al calor del estudio de la oratoria y de los procedimientos del orador. Se veía en la poesía una fuerza persuasiva que hoy nos es ajena o estamos lejos de reconocer en ella. Que ese efecto persuasivo no era una simple ilusión acústica o emocional, es lo que podría explicar tal vez el temor, casi pánico visceral, de Platón ante el influjo de la poesía sobre el ánimo del guerrero, o 
su capacidad para contrahacer la idea de la divinidad. Muy probablemente todo ello era el producto del enlace griego-arcaico entre poesía y música, que nunca terminaremos realmente de entender (aunque hoy sepamos algo más) ${ }^{7}$.

En décadas recientes esta estructura poética ha sido vista en términos y con los medios del estructuralismo, que prohíja una noción abstracta de la estructura, entendida como modelo del objeto y como tema principal, si no único, de reflexión. No hay duda que todo lector de un poema o de cualquier texto literario advierte que hay en ellos una lógica constructiva que es posible discernir, incluso describir, consistente en oposiciones (contrastes, antítesis) o solidaridades (complementariedad, reciprocidad, simetrías, etc.). Hay siempre, es claro, un repertorio mínimo en este juego de alternativas. Con todo, ningún rectángulo semiótico podrá dar cuenta de la riqueza de la obra singular. La insatisfacción que nos dejan los análisis concretos de Greimas (los dedicados a Maupassant y otros) habla por sí misma. Aquí, de un modo funcional, entendemos por estructura simplemente un conjunto de relaciones dinámicas entre los principales elementos que integran el texto. Por razones de espacio y en virtud de su interés intrínseco, nos concentramos especialmente en algunas imágenes y símbolos mayores.

La mención de la nieve, duplicada desde la apertura de la "Oda", apunta a una visión de plenitud. Se lo dice explícitamente: "en plena flor”. Esta visión se correlaciona con otras expresiones que matizan la imagen: "imprecisa", "temblando". La nieve es doblemente "imprecisa", en parte por lo inestable de su estado físico (sólido, líquido), pero más que nada en razón de que hay ínsita una alternativa en su temblorosa plenitud: la de ser un camino de agua benéfico, que conserve la pureza original, o ser en su curso ulterior flujo dañoso y destructivo. En esta posible bifurcación, hay ya una amenaza latente sobre este paisaje henchido de potencialidades. El río que nace en su nido cordillerano podrá ser fuente de fertilidad o de vida o, por el contrario, arma de muerte contra la carne de los inermes. El tercer verso, "párpado boreal, pequeño rayo helado", ya expresa esta dualidad, en su oposición geométrica y en la contradicción interna de "rayo helado". Por supuesto, algunas de estas significaciones se nos ofrecen de inmediato o las captamos en seguida; otras sólo afloran al releer el poema, una vez que reiniciamos su lectura con una comprensión, si no global, por lo menos preliminar.

\footnotetext{
${ }^{7}$ Véase el admirable artículo de Walker, Jeffrey: “The View from Halicarnassus: Aristotelianism and the Rhetoric of Epideictic Song”, 1998, pp. 17-48. Por otra parte, todavía Du Bellay (1522-1560) escribía en su Defensa e Ilustración de la Lengua Francesa: "Será poeta de verdad (...) quien me haga indignar, apaciguar, extasiarme, amar, odiar, admirar (...), en breve, el que tenga la brida de mis afectos”.
} 
En gran medida, la estructura temporal del poema consistirá justamente en desenvolver esta doble potencialidad subyacente, haciendo chocar los términos de la pareja antitética. Así, el primer movimiento interrogativo concluye en una simple yuxtaposición entre el elemento natural del río y las condiciones miserables existentes en el país y en la ciudad: "hasta donde tus aguas puras tocan / los horribles harapos de mi patria?". "Tocan”, nos dice el poeta; pero en este contacto las aguas siguen siendo "puras" y no participan de los "terribles harapos" que les salen al paso.

Es lo que cambia a continuación. Exactamente luego de la primera invocación (“Río, ...”) las cualidades materiales del agua se describen como "agua fría y secreta" y su nexo umbilical con lo alto ya muta parcialmente de sentido: "agua que el alba dura de las piedras...”. Esta mínima transición, todavía en germen, se magnifica brutalmente con posterioridad, cuando el río muestre todo su coeficiente hostil, no sólo con el apóstrofe "río amargo”, sino en el nuevo y reiterado: "oh, río / duro río”, que saca a flote la forma más hiriente y percutiente de la contraposición. De aguas puras que era el Mapocho cerca de su fuente y en su curso inicial, se convierte ahora en un río duro y enemigo del hombre. Pura, dura: toda la trasmutación negativa reside en partículas microscópicas de la lengua, en substituciones fonéticas elementales. Y lo duro y la dureza de lo líquido propagan su efecto, lo expanden a otras fuerzas naturales anti-humanas: "junto a la manga rota que el viento endurecido / hace temblar debajo de las hojas de hierro". La temblorosa "flor de nieve", signo alto de virtualidad, ha dado origen a un espectáculo urbano, de hierro, de metal... y de dolor. Frío duro, y ya no palpitante: temblor sin más de la piel y del cuerpo.

La metamorfosis está bien delineada por el arco temporal que traza el poema: "alba dura de las piedras" / "cuando la noche llega”. Ingresamos en una zona negra donde todo se oscurece bajo el signo del mal y de lo pésimo: "negra estatua”, "racimo negro de cabezas golpeadas", "agua negra”, “espuma negra”. Lo que era apenas contraste fonético y semántico en la identidad sucesiva del río, resulta ahora oposición cromática y sensorial, marcadísima en este caso: aguas puras, agua negra.

Este manto que envuelve opresivamente el poema se junta con los nuevos elementos materiales que empiezan a proliferar. Ya no se habla de "piedras", sino de "estatua" (pero la transición se hace fluida por la mención de "catedral inaccesible", que a menudo en el uso nerudiano es efigie de la naturaleza: cf. "Entrada a la Madera” y El Gran Océano), y se impone un panorama de puentes y de hierro. Del alba cordillerana hemos entrado en la noche capitalina. Lo urbano y lo social dominan; el río se "denigra” en una oscuridad que todo lo envuelve y pasa a ser agente destructor en una organización ella misma destructora. 
Ante esta situación, “por qué no te levantas...”, se exclama en una advocación crucial. Las causas y las fuerzas que son agentes de la transformación son las mismas necesidades básicas, el frío (por la falta de abrigo y de techo a la vez) y el hambre - ambas expresadas en una casi perfecta homonimia con lo que está en juego en el poetizar: frío/río y hambre/hombre. Neruda excava y explota la cantera diamantina del idioma y, frotando sonido contra sonido, la hace dúctil para extraer nuevos sentidos. He aquí las águilas prometeicas "inmensas” y el "inmenso fantasma” que las combate. La imagen es casi especular, una especie de quiasmo a la distancia. El símbolo del "fantasma" sabemos a qué remite y no exige glosa. El otro símbolo con que se evoca ese eventual "levantarse" del hombre es más complejo: "una nueva cruz de estrellas”. Nueva lo es esta "cruz" porque no coincide con la vieja y tradicional que bendice y eterniza el sufrimiento; es “de estrellas", porque no pertenece a un cielo trasmundano, sino que brota de la misma noche en que el pueblo está sumido. A través de estos potentes símbolos — símbolos de época, ígneos en su tiempo- el poeta comunica un mensaje revolucionario que ponga fin a "los piojos", a las "cabezas golpeadas” y al "sollozo" de una dolorida humanidad.

En definitiva, la invención imaginaria que circula en el poema se polariza en dos imágenes extremas, la "plena flor de nieve” del segundo verso y "la flor del fuego" en el verso penúltimo — disposición totalmente simétrica en la firme arquitectura que sostienen. Entre esos dos polos discurre un proceso claramente dialéctico, no en el sentido subjetivo-objetivo que antes indicábamos, sino ahora centrado en la conflictividad, en lo contradictorio, en el uso creador de la negación y en la superación activa de las antítesis que presenta la realidad. Si la primera estaba más cerca de la Fenomenología hegeliana (1807), esta otra dialéctica es más comprensible a la luz de los Manuscritos de 1844. En el "valle ceniciento" que media entre la nieve y el fuego, este último reenciende la rebelión y, de la "flor salvaje" que es expresión del estado de cosas real, busca fundar "la semilla del hombre".

\section{Un arte de ríos}

El motivo fluvial que inaugura la “Oda” recibe un despliegue sinfónico a través del vasto Canto General. Como en The Prelude (1850), de Wordsworth, el camino del poeta en la epopeya nerudiana es una paideia de aguas: lago secreto de uno, ríos rumorosos del otro. Más arriba recordábamos el umbral de la primera sección, La Lámpara en la Tierra. Los “ríos, ríos arteriales” que ahí se mencionan son el punto de partida de una visión continental atenta a la riqueza, variedad y fecundidad de las vías acuáticas. 
El gran motivo fluvial afirma la interdependencia de dos principios materiales, el agua y la tierra. Cinta líquida que fluye entre riberas terrestres, el río unifica esos principios cósmicos, los hermana primordialmente, y ello en un doble sentido: acoplándolos con fértil yugo elemental y enlazando, gracias a su curso, cuerpo terrestre y horizonte oceánico. Protoforma en plenitud, el río se asocia y forma familia con la arcilla y con la greda, vinculados al origen de la vida y al arte popular, y también con el "pozo... de verdades sumergidas" de que habla el poeta en Alturas de Macchu Picchu. De este modo, es figura central que expresa arquetípicamente el elementalismo y los elementos imaginarios básicos del Canto General.

Camino que viaja a lo largo y ancho del planeta; destino histórico de los pueblos (“Los países se tienden junto a los ríos”), el río es sobre todo trabajo, actividad práctica transformadora que se inscribe en las líneas de la tierra. Esta forma telúrica - modelo geológico del trabajo humano- se vierte en imágenes de esfuerzo, de empuje constructivo que brotan abundantemente en la antología fluvial de La Lámpara en la Tierra: “y arrastrabas los cauces de la arena / a través de la noche planetaria / (...) rompiendo en el camino / toda la sal de la geología / apartando los músculos del cuarzo" (iv, "Los Ríos Acuden”). Picapedrero, leñador en otros pasajes, constructor en general, el río traza un proceso de auconstrucción que da una base sólida y profunda al movimiento correlativo de la especie humana.

Esta visión natural, geográfica y continental de los ríos —que es, además, un homenaje al esplendor de la toponimia americana, en lo fundamental aborigen (Orinoco, Tequendama, Bío-Bío) — halla en el otro extremo del libro un múltiple correlato humano, Los Ríos del Canto. Lo que fluye ahora, en la sección XII, es el cauce de la poesía, la voz de escritores, poetas, músicos, todos amigos del poeta, anticipados en cierto respecto por los cuatro amigos chilenos del Canto General de Chile, todos los cuales representan prototipos de una humanidad libre, creativa, generosa. El primer poema, dedicado al venezolano Miguel Otero Silva, contiene una estupenda definición de la historia americana que calza con lo que venimos exponiendo: "Porque así ha sido nuestra América: / una llanura con ríos devorantes y constelaciones / de mariposas... (...) pero siempre a lo largo de la noche y de los ríos / hay tobillos que sangran” (XII, i). Sucesivamente, el poema a Alberti está presidido por el nombre del Genil, el dedicado al argentino González Carbalho enjoyado por el Río de la Plata, etc. Y el río enterrado que circula secretamente, tras todos estos poemas, sin jamás emerger, es sin duda García Lorca —río tras los ríos, muerto tras los muertos y los que aún viven. Los Ríos del Canto son, en su clave más íntima, una corona funeral para el amigo profundo asesinado al inicio de la Guerra Civil Española. Es el hilo subterráneo que enhebra todo el cántico. 
La importancia de esta visión nerudiana de los ríos puede aquilatarse, aunque sea brevemente, comparándola con lo que Sarmiento escribió sobre el mismo tema un siglo antes, en su gran ensayo Facundo (1845). En éste hay una amplia y poderosa descripción de los ríos americanos, principalmente de aquéllos en territorio argentino o del antiguo Virreinato del Plata. Con todo, la percepción de estos ríos responde en Sarmiento a un modelo que les es externo, el de la geografía y el curso de los ríos en la América del Norte. Las aguas del norte de la pampa, entre el Atlántico y el interior, vienen a ser el reflejo de un reino platónico de ríos que fluyen —eterna, paradigmáticamente- en el este y en el sur de los Estados Unidos. Visión liberal, comercial, capitalista utópica si se quiere, a la manera de Smith o de Tocqueville, de las grandes vías acuáticas norteamericanas. Éstas son medios de comunicación, canales por donde ha de circular la riqueza y la prosperidad del continente —ojalá también en la nueva Argentina.

La visión nerudiana se sitúa en los antípodas de esta perspectiva. Célula del trabajo y del élan constructivo, el río es el centro de una intuición ciclópea, afín en lo esencial al titanismo de la pintura mexicana. Figura de la historia y del pathos revolucionario, en el pobre Mapocho que hemos estado recorriendo, el fluvialismo está más cerca de la praxis y del finalismo humano, no del determinismo económico o de fuerzas puramente mecánicas. Hilo cristalino de amistad y fraternidad entre poetas, materia de su voz innumerable, el río es por último encarnación libre y ambulante de una cierta humanidad. Estos ríos-poetas están del lado de una libertad que tiene orillas, cauce y lecho en esta tierra. Vienen de las entrañas más puras del planeta y trazan un camino de barro y de nieve para crear, o ayudar a la creación, de la "semilla del hombre".

Concluyendo ya este apartado, naturaleza, historia y poesía se conjugan como tres dimensiones o terrazas de un mismo motivo. Ríos sudamericanos al comienzo, cristalización de un proyecto de cambio y de rebelión en el centro, ríos que son voces vivientes o enterradas del cántico hacia el fin: el fluvialismo raigal de la imaginación nerudiana se expande y ramifica en una ingente tríada. La “Oda” comentada es el embrión más temprano de este mural en gran escala.

\section{Conclusión}

El comentario de textos halla su ámbito natural en la sala de clases o en el seminario de tema monográfico. Esto último parece redundante, pero en las circunstancias actuales de enseñanza de la literatura, es casi una afirmación de principios. El texto literario ha dejado de ser objeto de estudio, 
lo "literario" sólo reviste un interés marginal. Ni la experiencia del texto como forma plasmada ni los mecanismos internos de su artesanía son foco del análisis. Su especificidad se diluye o se pierde al hacerse parte de otras series de documentos (testimonios, etc.), de otros conjuntos en la cultura comercial, o de campos misceláneos de estudio.

En el intercambio que constituye la experiencia docente, es posible comunicar oralmente, a veces por un simple gesto, la necesaria atención al detalle y a los hechos minúsculos que conforman la materialidad del poema. Las aliteraciones, el juego eufónico, la andadura rítmica del verso o el ensamblaje de la estrofa, se pueden observar y discutir allí, sin caer (falibilidades aparte) en lo obvio o en lo pedante. Pues son éstos los pecados capitales que amenazan, cuando se intenta trasladar los resultados de un comentario a una versión en letra impresa.

En realidad, no existe hasta la fecha una estrategia expositiva convincente para presentar el comentario de texto. Por su aspecto pedagógico, uno de sus fines cuando se lo emprende, debería presentarse como algo sumamente ordenado, dispuesto rigurosamente en momentos y planos del análisis, lo cual lo hace inevitablemente rígido, cuando no fastidioso en demasía. Es buena la pedagogía, pero no para tanto. O tiende a convertirse en algo minucioso, excesivo, de nunca acabar. Las Microlecturas de JeanPierre Richard, indudable maestro en el análisis de poesía del cual todos hemos aprendido, no están exentas de estos defectos ocasionales. Basta ver su glosa al gran poema baudelairiano El Balcón, preferido de Valéry, que se empantana en el microcomentario del nivel fónico del poema — de gran interés ciertamente, pero que no se comunica al lector de un modo eficaz ${ }^{8}$.

En este pasaje del diálogo al texto impreso hay dos obstáculos por lo menos que se me imponen con mayor nitidez: la mezcla de discursos y de saberes en juego a los que hay que recurrir, y el distingo entre la fase analítica y el momento de síntesis que debe seguir. Hasta cierto punto, todo cabe o puede caber en el comentario de textos, en la medida en que texto, intérprete y eventual lector participan de un universo común de cosas consabidas, que circulan como bienes intelectuales en la comunidad cultural a que se pertenece. A Eleazar Huerta, otro maestro de la estilística en Chile, le gustaba subrayar la dimensión de lo consabido como terreno de base para la comprensión de un texto. Los contornos resultan amorfos, ostensiblemente vagos, y sólo el tacto del comentarista puede decidir lo que se incluye y lo que debe ser excluido. Por otro lado, la síntesis o recapitulación de los resultados a que se ha llegado siempre deja que desear, porque su

${ }^{8}$ Cf. Richard, J. P.: “Mettons-Nous au Balcon”, 1984, pp. 9-20. 
alcance no puede competir con la impresión y el efecto del poema. Si lo enriquece en pistas de sentido, lo empobrece fatalmente en su percepción de conjunto. Y aunque el lector esté consciente de que se trata de cosas de orden muy diverso, tiende tácitamente a medir lo inconmensurable. (Yo mismo acabo de hacerlo en relación con J. P. Richard.) De algunos de estos problemas ha hablado G. Genette con justeza y sensatez:

Su función cardinal (del ensayo crítico) es pues de comentario, o sea un mixto, de dosis variables y a decir verdad indiscernibles, de descripción, de interpretación y de evaluación tácita (...) El comentario es por naturaleza infinito, siempre renovable, desprovisto como está (y así lo quiere) de toda eficacia práctica mensurable ${ }^{9}$.

Aunque lo último es un lugar común, y por ello mismo muy válido, estas observaciones reflejan bien lo que el intérprete percibe y el carácter oscuramente híbrido del género que uno se aventura a practicar y a cultivar - en parte por gusto, en parte por destino profesional. Así, con esta caución de fondo, pasamos a resumir los resultados de nuestro análisis del sobresaliente poema nerudiano.

Hace ya bastante tiempo, en memorables páginas contenidas en su libro La Poesía de Rubén Darío, Pedro Salinas analizó la estructura del poema “A Roosevelt”, clave de bóveda de los Cantos de Vida y Esperanza (1905). Mostraba allí el crítico español (notable poeta también) que el poema se articulaba en dos monosílabos básicos del idioma, un "No" rotundo dirigido a la interferencia norteamericana después de Cuba y Panamá, y un "Dios" final, al cual el centroamericano cargaba con toda su herencia hispana y católica de la América de abajo. Entre ese "No" enérgico y este "Dios" generosamente excluyente reposaba todo el armazón poético que Salinas constataba en la oda.

Es curioso que, treinta y tantos años más tarde, otra oda de inspiración muy diferente responda a un esquema similar. Las partículas primordiales son ahora un par de exclamaciones, un "No" fortísimo en posición nodal y una antítesis final de la fórmula cristiana, con que se rechazan los dictados de la realidad tal como ésta se presenta. "Oh, sí, No, Que no sea” es el cordaje que teje y tensa la estructura del poema, su sintaxis más escueta y perceptible.

Entre esos átomos diminutos de la lengua se despliega un cántico al Mapocho, que primero lo ve en su cuna andina con el aura resplandeciente

${ }^{9}$ Genette, G.: Figures V., 2002, p. 11. 
de la nieve, luego lo mira descender al pobre y ceniciento Valle Central, lo mimetiza en seguida con una noche del hambre y del frío en medio de la ciudad, para izar de allí un mensaje de lucha y rebelión que se cifra en imágenes potentes y en dos símbolos ideológicos —el fantasma del Manifiesto $^{10}$ y el emblema transcristiano de una "nueva cruz de estrellas". Rechazo final al estado de cosas existente, "Oh, que no sea” —anti-Amén materialista - clausura un poema que busca rescatar y fundar "la semilla del hombre”. Gravemente, acongojadamente, con ira y con dolor, a veces con desesperación, el poeta moviliza un turbión emocional que toca y se adentra en el corazón del lector.

\section{Posdata}

Como ya se ha visto, Neruda escribe la "Oda” en 1938, publicándola el mismo año. Aunque muy a la defensiva, la República Española no ha sido aún completamente derrotada. En Chile existe un clima político y cultural renovador. Muy pronto gobernará el país una alianza político-social que lleva el mismo nombre del Frente Popular que falló en Francia y que sigue combatiendo en la Península. Este gobierno y las fuerzas que lo apoyan participan en un alba histórica al poner en marcha importantes medidas y programas económicos, en medio de un activo despertar nacionalista y populista que se expresa en gran variedad de manifestaciones culturales. El Frente Popular se aguará, sin embargo, bajo la administración Ríos, para llegar a la franca traición hacia fines de los 40 , por efectos de la proyección de la Guerra Fría en el sur del continente. El Canto General se escribe entre la alborada del 38 y la represión del 48, dando cabida a sentimientos opuestos de esperanza y de cólera, de euforia y decepción. El poeta que cantó a su patria en la "Oda al Río Mapocho de Invierno" es ahora perseguido por el mismo gobierno que contribuyera a elegir. Con visión muy parecida, pero con un tono a todas luces contrapuesto, río y ciudad reaparecen en la sección de El Fugitivo: "Al cruzar la ciudad la noche andina / la noche derramada abrió su rosa / sobre mi traje. / Era invierno en el Sur. / La noche había / subido a su alto pedestal, el frío / quemaba con mil puntas congeladas. / El río Mapocho era de nieve negra. / (...) todo era mío, / todo hacia mí en el silencio levantaba / una boca de amor llena de besos” (iii).

El poeta es ahora él mismo un río clandestino, podríamos decir, para quien el frío nocturno se deshace ante la fusión solidaria con su pueblo.

\footnotetext{
${ }^{10}$ El símbolo prometeico se relaciona no sólo con la concepción marxista, sino con el radicalismo de Shelley, una suerte de liberal-anarquismo increíble para su tiempo.
} Esto, obviamente, sin que implique un nexo intertextual explícito. 
Hoy, casi setenta años después, muchas cosas han cambiado. Mucha agua ha pasado bajo los puentes; mucha sangre también. En este tiempo de bajamar ideológica, un compromiso político como el que muestra Neruda parece ser algo anacrónico, una fe de otra época. El intervalo cronológico entre texto y comentario se revela entonces, por la distancia hermenéutica que instituye, como contraste de dos horizontes mentales. Si el milagro posdictatorial y el halo de la globalización deslumbran sombríamente a la sociedad, rescatar una llamarada de poesía quizá sirva para iluminar, a contraluz y a contracorriente, una "semilla del hombre" que tal vez, tal vez (como diría Neruda) no fue sembrada en vano.

\section{BIBLIOGRAFÍA}

Aguirre, Margarita: Genio y Figura de Pablo Neruda. Colección “Genio y Figura”. Buenos Aires: Editorial Universitaria, 1964.

Bréal, Michel: Essai de Sémantique. Science des Significations. París: Hachette, 1924.

Concha, Jaime: “A Orillas del Canto General”. Ponencia de 1993, leída en Oxford, inédita.

Dilthey, Wilhelm: Introducción a las Ciencias del Espíritu (1883). Trad. de Eugenio Imaz. México: Fondo de Cultura Económica, 1944.

Genette, Gerard: Figures V. París: Seuil, 2002.

Hegel, G. W. F.: Vorlesungen uber die Aesthetik. Frankfurt a.M.: Suhrkamp Verlag, 1970.

Loyola, Hernán: “Guías Bibliográficas”. En Pablo Neruda: Obras Completas, Tomo II. Buenos Aires: Editorial Losada, $3^{\mathrm{a}}$ ed., 1968.

Lukács, Georg: Estética. Trad. De M. Sacristán. Barcelona-México: Grijalbo, 1967.

Lukács, Georg: Teoría de la Novela. Buenos Aires: Ediciones Siglo XX, 1974.

Martínez Bonati, Félix: La Estructura de la Obra Literaria: Una Investigación de Filosofía del Lenguaje y Estética. Santiago: Ediciones de la Universidad de Chile, 1960.

Martínez Bonati, Félix: La Concepción del Lenguaje en la Filosofía de Husserl. Santiago: Anales de la Universidad de Chile, 1960.

Neruda, Pablo: Canto General. Ed. de Enrico Mario Santí. Madrid: Cátedra, 1990.

Richard, Jean Pierre: “Mettons-Nous au Balcon”. En Jean Pierre Richard, Pages Paysages Microlectures, II. París: Seuil, 1984.

Spitzer, Leo: Linguística e Historia Literaria. Madrid: Gredos, 2a ed., 1961.

Spitzer, Leo: La Enumeración Caótica en la Poesía Contemporánea. Trad. de Raimundo Lida. (Colección de Estudios Estilísticos). Buenos Aires: Imprenta Coni, 1945.

Walker, Jeffrey: "The View from Halicarnassus: Aristotelianism and the Rhetoric of Epideictic Song”. En Mark Jeffreys (ed.), New Definitions of Lyric. New York: Garland Publishing, Inc., 1998. 